\title{
Quality of life in chronic heart failure: cilazapril and captopril versus placebo
}

\author{
C J Bulpitt, A E Fletcher, L Dössegger, A Neiss, T Nielsen, S Viergutz, on behalf of the \\ Cilazapril-Captopril Multicentre Group
}

Epidemiology Research Unit, Division of Geriatric Medicine,

Hammersmith

Hospital, Imperial

College of Medicine, London, UK

C J Bulpitt

London School of Hygiene and Tropical Medicine, London, UK A E Fletcher

Department of Clinical Research, F Hoffmann La-Roche, Basel, Switzerland

L Dössegger

$\mathrm{T}$ Nielsen

Institute für Medizische Statistik und Epidemiologie der

Technischen,

Universität München, Germany

A Neiss

Gesellschaft für angewandte Mathematik und Informatik (GMI), Munich, Germany $S$ Viergutz

Correspondence to: Professor C J Bulpitt, Division of Geriatric Medicine, Royal Postgraduate Medical School, Du Cane Road, London W12 0NN, UK.

\begin{abstract}
Objective-To measure quality of life (QOL) in patients with mild to moderate heart failure treated with angiotensin converting enzyme (ACE) inhibitors cilazapril or captopril.
\end{abstract}

Design-Randomised, double blind, placebo controlled, parallel groups trial.

Subjects-367 patients with New York Heart Association (NYHA) heart failure class II $(62 \%)$, III $(36 \%)$ or IV $(1 \%)$.

Methods-Patients were randomised to receive cilazapril $1 \mathrm{mg}$ daily $(n=191)$ or captopril $25 \mathrm{mg}$ three times daily $(\mathrm{n}=90)$ for 24 weeks, or placebo for 12 weeks followed by cilazapril $1 \mathrm{mg}$ daily for a further 12 weeks $(n=86)$. If patients had not responded after four weeks cilazapril was increased to $2.5 \mathrm{mg}$ daily and captopril to $50 \mathrm{mg}$ three times daily. QOL was assessed at baseline, 12 , and 24 weeks using the sickness impact profile (SIP), the profile of mood states (POMS), the Mahler index of dyspnoea-fatigue, and a health status index (HSI).

Results-The physical dimension of the SIP averaged 7 units at baseline and improved after 12 weeks by 2.24 units in the cilazapril group, 2.38 units in the captopril group, and 1.51 units in the placebo group. The difference between drug and placebo was therefore 0.73 units $(95 \%$ CI $\mathbf{- 0 . 8 6}$ to 2.32) for cilazapril, and 0.87 units (95\% CI -0.96 to 2.70 ) for captopril, with small non-significant effect sizes (a statistical method for estimating the importance of a treatment related change) of 0.12 and 0.14 . Similar results were observed for the total POMS and HSI scores. Although QOL improved more on the ACE inhibitors than on placebo, the effect sizes were not significant $(\leqslant 0.26)$.

Conclusions-Improvements in QOL in mild to moderate heart failure were small when treated with cilazapril or captopril compared with placebo.

(Heart 1998;79:593-598)

Keywords: congestive heart failure; quality of life; randomised controlled trial; cilazapril; captopril; ACE inhibitors

The cooperative north Scandinavian enalapril survival study (CONSENSUS), ${ }^{1}$ the second vasodilator heart failure trial (V-HeFT II), ${ }^{2}$ and the studies of left ventricular dysfunction (SOLVD) trials ${ }^{3}$ have all shown a reduction in mortality of heart failure patients treated with angiotensin converting enzyme (ACE) inhibitors. ACE inhibitors have also been shown to increase survival when heart failure follows acute myocardial infarction ${ }^{4}$ and probably to reduce infarction rates. ${ }^{5}$

Management of patients with congestive heart failure (CHF) aims not only to increase survival but also to improve quality of life (QOL). However, there have been few QOL randomised, double blind studies of $\mathrm{CHF}$. Giles et al suggests that a long acting ACE inhibitor may be more suitable than a short acting one. ${ }^{6}$ We therefore measured QOL in patients treated with the long acting ACE inhibitor cilazapril, the short acting drug captopril, or placebo. ${ }^{7}$ Both cilazapril ${ }^{8}$ and captopril $^{9}$ are associated with acute improvements in haemodynamic measurements, which appear to be attenuated when these effects are measured during long term treatment. ${ }^{8} \mathrm{Im}$ provements in QOL were therefore expected with long acting ACE inhibitor treatment.

\section{Methods}

A double blind, placebo controlled trial was performed in 12 different countries including Europe, Israel, Canada, and Australia. After a two week single blind placebo run-in phase, patients were randomised to receive cilazapril, captopril, or placebo in a ratio of $2: 1: 1$. Treatment started with $0.5 \mathrm{mg}$ cilazapril once daily or $6.25 \mathrm{mg}$ captopril three times daily. At the end of the first week the dose was increased to $1 \mathrm{mg}$ cilazapril once daily or $25 \mathrm{mg}$ captopril three times daily. After four weeks the patients who had not responded adequately had their medication increased to $2.5 \mathrm{mg}$ cilazapril once daily or $50 \mathrm{mg}$ captopril three times daily. Double blinding was maintained as all patients received three capsules every day (including those receiving placebo). Patients were required to take their medication one hour before or two hours after the intake of food.

After 12 weeks of treatment all patients on cilazapril or captopril continued their treatment for a further 12 weeks. Patients taking placebo were switched to cilazapril, the dose increasing from $0.5 \mathrm{mg}$ to $2.5 \mathrm{mg}$ as necessary and according to the protocol for the previous 12 weeks. The last 12 weeks of the study were also double blind for the first two groups.

ENTRY AND EXCLUSION CRITERIA

Patients had to have chronic heart failure (more than three months) New York Heart Association (NYHA) class II, II, or IV ${ }^{10}$; been clinically stable on digoxin and/or diuretics; be over 18 years; and to have stopped taking $\beta$ 
adrenergic antagonists, calcium antagonists, and positive inotropes (apart from digoxin) at least 36 hours before entry (ACE inhibitors had to be omitted at least one week before entry). Patients provided informed consent and each centre had ethical committee approval. Haemodynamic criteria were not required.

Patients were excluded if they had: myocardial infarction or stroke within the previous three months; surgery for primary valvar disease; a pacemaker; or systolic blood pressure $<90 \mathrm{~mm} \mathrm{Hg}$. Exercise testing was performed at baseline and after $4,8,12$, and 24 weeks.

QUALITY OF LIFE MEASUREMENT

We used a general health profile (the sickness impact profile (SIP)), ${ }^{11}$ and a measurement of mood (the profile of mood states (POMS)), ${ }^{12}$ supplemented by questions to assess dyspnoea, ${ }^{13}$ and to ascertain the impact of ill health on leisure and regular activities. ${ }^{14}$ The health status index (HSI $)^{14}$ was calculated from responses to the questionnaire. The selection of questions followed the general principles of measuring QOL in CHF. ${ }^{15}{ }^{16}$ Work performance was considered irrelevant owing to the age of the patients in the study.

The questionnaire assessed the following:

(1) The SIP - consisting of 12 dimensions: ambulation, mobility, body care and movement, social interaction, communication, alertness, emotional behaviour, sleep and rest, eating, work, home management, and recreation and pastimes. ${ }^{11}$

(2) The POMS - consisting of six subscales relating to tension-anxiety, depressiondejection, anger-hostility, vigour-activity, fatigue-inertia, and confusionbewilderment. $^{12}$

(3) The inability of patients to carry out regular activities. ${ }^{14}$

(4) The number of hobbies and whether treatment of the patient's heart condition or heart failure interfered with them. ${ }^{14}$

(5) The Mahler index of dyspnoea-fatigueconsisting of three subscales, and adapted for fixed and direct questions to enable standardisation of the results. ${ }^{13}$

(6) The HSI-derived from the activity information collected directly or included in the SIP. ${ }^{14}$ The higher the index the better the QOL. Two questions in the SIP identified patients who were confined to bed or room (score 0.125); two questions identified patients confined to home (score 0.375); and three questions identified patients who were very disabled (score 0.5 ). For patients who did not fall into these categories the questions on activity, and the number of days a month they were unable to work or perform regular activities were used to identify those who were disabled (score 0.625 ) or had a major disability (score 0.75). Questions on whether the heart condition or its treatment interfered with life or hobbies detected patients with minor disability (score 0.8 ). For patients not falling into these categories, discomfort, slight discomfort, and minor dissatis- faction were scored as follows: last total SIP score $\geqslant 4, \mathrm{HSI}=0.875$; last score $1-3, \quad$ HSI $=0.923$; last score 0 , HSI $=0.975$. To carry out an intention to treat analysis, all HSI scores were multiplied as follows: death $(\times 0)$, lost to follow up $(\times 0.85)$, withdrawn for insufficient therapeutic response $(\times 0.75)$, refused treatment $(\times 0.85)$.

QOL was assessed at entry to the trial and after 12 and 24 weeks, or at the final visit whenever possible. Careful attention was paid to translating the questionnaires from English using standard methods of translation and back translation. The questionnaire was self administered except for the Mahler index and patients were provided with a quiet room where they could complete the questionnaire at rest and without interruption. Before the start of the trial, all study nurses and investigators attended a two day training session to standardise the procedures for questionnaire completion.

\section{QUALITY CONTROL}

The QOL questionnaires were reviewed independently by quality control procedures to ensure that the Mahler index was completed by an interviewer and not the patient, the remainder of the questionnaire competed by the patient, and that the questionnaire was consistent and completed to an acceptable standard.

\section{STATISTICAL METHODS}

All analyses were completed on an intention to treat basis. The Mahler index and POMS results were analysed if more than $80 \%$ of the responses on each subscale were completed. Changes in QOL scores among the groups were compared using appropriate parametric and non-parametric statistical tests. Changes from baseline to 12 weeks and from 12 to 24 weeks were calculated. The changes reported are not adjusted for baseline or other variables. The effect size, a statistical method for estimating the importance of a treatment related change, ${ }^{17} 18$ was calculated from the between drug (or placebo) changes divided by the pooled standard deviation at baseline. The average change with placebo was subtracted from the average change with active drug to give the between drug changes. In general, an effect size of 0.3 indicates a small effect, 0.5 a moderate effect, and $\geqslant 0.8$ a large effect. The number of patients entered into the trial was designed to detect a change in exercise test time of one minute at the $5 \%$ level of significance and $80 \%$ power.

\section{Results}

Altogether, 443 patients from 35 centres were randomised, 367 patients had acceptable data on QOL, and 400 provided intention to treat data on exercise time. Eighty six per cent of the 443 patients had received a diuretic in the previous three months but only $11 \%$ had received an ACE inhibitor: $12 \%$ of the placebo group, $10 \%$ of the cilazapril group, and $14 \%$ of the captopril group. Four centres did not take part in the QOL project and one centre was 
Table 1 Sickness impact scores at baseline and mean (SEM) changes between 12 weeks and baseline, and 24 weeks and 12 weeks

\begin{tabular}{|c|c|c|c|c|c|c|c|c|c|}
\hline \multirow[b]{2}{*}{$\begin{array}{l}\text { Dimension } \\
\text { (range) }\end{array}$} & \multicolumn{3}{|c|}{ Cilazapril $(n=182)^{\star}$} & \multicolumn{3}{|c|}{ Captopril $(n=87)^{\star}$} & \multicolumn{3}{|c|}{ Placebo/cilazapril $(n=82) *$} \\
\hline & Baseline & $\begin{array}{l}\text { Change } \\
12-0\end{array}$ & $\begin{array}{l}\text { Change } \\
24-12\end{array}$ & Baseline & $\begin{array}{l}\text { Change } \\
12-0\end{array}$ & $\begin{array}{l}\text { Change } \\
24-12\end{array}$ & Baseline & $\begin{array}{l}\text { Change } \\
12-0\end{array}$ & $\begin{array}{l}\text { Change } \\
24-12\end{array}$ \\
\hline $\begin{array}{l}\text { Ambulation } \\
(0-50)\end{array}$ & 11.85 & $\begin{array}{l}-3.90 \\
(0.67)\end{array}$ & $\begin{array}{l}-0.93 \\
(0.48)\end{array}$ & 13.87 & $\begin{array}{l}-4.14 \\
(1.01)\end{array}$ & $\begin{array}{l}+0.25 \\
(0.80)\end{array}$ & 11.80 & $\begin{array}{l}-2.57 \\
(1.01)\end{array}$ & $\begin{array}{l}-0.98 \\
(0.89)\end{array}$ \\
\hline $\begin{array}{l}\text { Mobility } \\
(0-92)\end{array}$ & 7.01 & $\begin{array}{l}-2.77 \\
(0.84)\end{array}$ & $\begin{array}{l}-0.42 \\
(0.50)\end{array}$ & 7.96 & $\begin{array}{l}-2.37 \\
(1.13)\end{array}$ & $\begin{array}{l}+0.63 \\
(0.84)\end{array}$ & 6.53 & $\begin{array}{l}-0.70 \\
(1.22)\end{array}$ & $\begin{array}{l}-1.72 \\
(0.81)\end{array}$ \\
\hline $\begin{array}{l}\text { Body care and movement } \\
(0-53)\end{array}$ & 4.79 & $\begin{array}{l}-1.35 \\
(0.40)\end{array}$ & $\begin{array}{l}-0.17 \\
(0.32)\end{array}$ & 6.58 & $\begin{array}{l}-1.65 \\
(0.55)\end{array}$ & $\begin{array}{l}-0.58 \\
(0.60)\end{array}$ & 5.47 & $\begin{array}{l}-1.36 \\
(0.80)\end{array}$ & $\begin{array}{l}-1.29 \\
(0.59)\end{array}$ \\
\hline $\begin{array}{l}\text { Physical dimension } \\
(0-47)\end{array}$ & 6.88 & $\begin{array}{l}-2.24 \\
(0.44)\end{array}$ & $\begin{array}{l}-0.40 \\
(0.29)\end{array}$ & 8.58 & $\begin{array}{l}-2.38 \\
(0.59)\end{array}$ & $\begin{array}{l}-0.14 \\
(0.50)\end{array}$ & 7.18 & $\begin{array}{l}-1.51 \\
(0.72)\end{array}$ & $\begin{array}{l}-1.30 \\
(0.60)\end{array}$ \\
\hline $\begin{array}{l}\text { Social interaction } \\
\quad(0-91)\end{array}$ & 10.35 & $\begin{array}{l}-2.25 \\
(0.68)\end{array}$ & $\begin{array}{l}-1.23 \\
(0.55)\end{array}$ & 12.15 & $\begin{array}{l}-1.86 \\
(1.12)\end{array}$ & $\begin{array}{l}0.67 \\
(0.96)\end{array}$ & 13.48 & $\begin{array}{l}-3.78 \\
(1.29)\end{array}$ & $\begin{array}{l}-1.92 \\
(1.10)\end{array}$ \\
\hline $\begin{array}{l}\text { Communication } \\
(0-62)\end{array}$ & 4.14 & $\begin{array}{l}-1.29 \\
(0.65)\end{array}$ & $\begin{array}{l}+0.27 \\
(0.41)\end{array}$ & 4.74 & $\begin{array}{l}-1.37 \\
(1.03)\end{array}$ & $\begin{array}{l}+0.22 \\
(0.85)\end{array}$ & 4.09 & $\begin{array}{l}-1.02 \\
(0.96)\end{array}$ & $\begin{array}{l}-0.61 \\
(0.42)\end{array}$ \\
\hline $\begin{array}{l}\text { Alertness } \\
(0-90)\end{array}$ & 12.89 & $\begin{array}{l}-3.40 \\
(1.09)\end{array}$ & $\begin{array}{l}+0.12 \\
(0.79)\end{array}$ & 18.81 & $\begin{array}{l}-6.61 \\
(1.83)\end{array}$ & $\begin{array}{l}-1.61 \\
(1.54)\end{array}$ & 15.44 & $\begin{array}{l}-4.26 \\
(1.94)\end{array}$ & $\begin{array}{l}-3.16 \\
(1.55)\end{array}$ \\
\hline $\begin{array}{c}\text { Emotional } \\
(0-81)\end{array}$ & 6.48 & $\begin{array}{l}-2.35 \\
(0.81)\end{array}$ & $\begin{array}{l}-0.15 \\
(0.39)\end{array}$ & 8.00 & $\begin{array}{l}-2.23 \\
(1.10)\end{array}$ & $\begin{array}{l}+0.16 \\
(1.01)\end{array}$ & 7.03 & $\begin{array}{l}-1.72 \\
(1.34)\end{array}$ & $\begin{array}{l}-1.79 \\
(0.77)\end{array}$ \\
\hline $\begin{array}{l}\text { Psychosocial dimension } \\
\quad(0-63)\end{array}$ & 8.95 & $\begin{array}{l}-2.32 \\
(0.57)\end{array}$ & $\begin{array}{l}-0.44 \\
(0.37)\end{array}$ & 11.30 & $\begin{array}{l}-2.84 \\
(0.90)\end{array}$ & $\begin{array}{l}-0.53 \\
(0.87)\end{array}$ & 10.73 & $\begin{array}{l}-2.94 \\
(1.08)\end{array}$ & $\begin{array}{l}-1.90 \\
(0.81)\end{array}$ \\
\hline $\begin{array}{l}\text { Sleep and rest } \\
(0-88)\end{array}$ & 12.65 & $\begin{array}{l}-1.98 \\
(0.87)\end{array}$ & $\begin{array}{l}-1.36 \\
(0.78)\end{array}$ & 18.04 & $\begin{array}{l}-5.13 \\
(1.59)\end{array}$ & $\begin{array}{l}+1.00 \\
(1.50)\end{array}$ & 14.02 & $\begin{array}{l}-4.13 \\
(1.52)\end{array}$ & $\begin{array}{l}-1.05 \\
(1.07)\end{array}$ \\
\hline $\begin{array}{l}\text { Eating } \\
\quad(0-39)\end{array}$ & 3.51 & $\begin{array}{l}-0.81 \\
(0.32)\end{array}$ & $\begin{array}{l}-0.15 \\
(0.32)\end{array}$ & 3.82 & $\begin{array}{l}-1.03 \\
(0.50)\end{array}$ & $\begin{array}{l}+0.38 \\
(0.44)\end{array}$ & 3.97 & $\begin{array}{l}-0.50 \\
(0.50)\end{array}$ & $\begin{array}{l}-0.62 \\
(0.37)\end{array}$ \\
\hline $\begin{array}{l}\text { Work } \\
\qquad(0-87)\end{array}$ & 16.65 & $\begin{array}{l}-1.49 \\
(2.09)\end{array}$ & $\begin{array}{l}-0.38 \\
(2.01)\end{array}$ & 22.10 & $\begin{array}{l}-4.81 \\
(3.63)\end{array}$ & $\begin{array}{l}+0.52 \\
(2.99)\end{array}$ & 15.86 & $\begin{array}{l}-3.88 \\
(3.44)\end{array}$ & $\begin{array}{l}-0.07 \\
(3.15)\end{array}$ \\
\hline $\begin{array}{l}\text { Home management } \\
(0-87)\end{array}$ & 14.39 & $\begin{array}{l}-3.34 \\
(1.00)\end{array}$ & $\begin{array}{l}-0.30 \\
(0.83)\end{array}$ & 18.79 & $\begin{array}{l}-4.01 \\
(2.11)\end{array}$ & $\begin{array}{l}-0.24 \\
(1.39)\end{array}$ & 14.03 & $\begin{array}{l}-2.49 \\
(1.26)\end{array}$ & $\begin{array}{l}-1.45 \\
(1.55)\end{array}$ \\
\hline $\begin{array}{l}\text { Recreation } \\
\quad(0-88)\end{array}$ & 18.33 & $\begin{array}{l}-4.55 \\
(1.11)\end{array}$ & $\begin{array}{l}-2.89 \\
(1.06)\end{array}$ & 20.23 & $\begin{array}{l}-4.87 \\
(2.00)\end{array}$ & $\begin{array}{l}+0.03 \\
(1.67)\end{array}$ & 16.43 & $\begin{array}{l}-3.59 \\
(1.51)\end{array}$ & $\begin{array}{l}-1.72 \\
(1.53)\end{array}$ \\
\hline $\begin{array}{l}\text { Total } \\
\quad(0-48)\end{array}$ & 9.17 & $\begin{array}{l}-2.29 \\
(0.45)\end{array}$ & $\begin{array}{l}-0.54 \\
(0.28)\end{array}$ & 11.57 & $\begin{array}{l}-2.93 \\
(0.69)\end{array}$ & $\begin{array}{l}-0.16 \\
(0.60)\end{array}$ & 9.88 & $\begin{array}{l}-2.37 \\
(0.73)\end{array}$ & $\begin{array}{l}-1.42 \\
(0.57)\end{array}$ \\
\hline
\end{tabular}

A high score indicates a poor QOL. Maximum score is 100 , minimum 0 .

^Number of patients providing information at both 0 and 12 weeks.

excluded because of incomplete data. Of the 367 patients in the QOL study, 191 were randomised to receive cilazapril throughout, 90 to receive captopril throughout, and 86 to receive placebo for 12 weeks followed by cilazapril for 12 weeks. Sixty four per cent of the 400 intention to treat patients were men; $62 \%$ were NYHA class II, $36 \%$ class III, and $1 \%$ class IV; the average age of the patients was 63 years (range 21 to 87 ) - there was no difference among the groups in these respects. Baseline QOL measures did not differ statistically among the groups but some differences were possibly important-for example, the average total SIP score was 9.2 at baseline in the cilazapril group and 11.6 in the captopril group (table 1).

After 24 weeks, QOL data were available for $182(95 \%)$ patients who received cilazapril throughout, $86(96 \%)$ who received captopril throughout, and 80 (93\%) who received placebo then cilazapril. Eight of the 443 patients died during the course of the trial, five in the cilazapril group, two in the captopril group, and one in the placebo group (randomisation ratio was $2: 1: 1$ ). Three patients died in the first 12 weeks and five in the second.

Table 1 gives the results for the individual SIP dimensions and for the subscales: physical dimension score (three dimensions), psychosocial score (four dimensions), and total score. The baseline values for each dimension are given for the three groups as well as the change between 12 and 0 weeks and 24 and 12 weeks. The effect of treatment with cilazapril for 12 weeks was the difference between the result at 12 weeks and baseline for the group randomised to continuous cilazapril, or the difference between 24 weeks and 12 weeks in the

Table 2 Profile of mood states (POMS) scores at baseline and mean (SEM) changes

\begin{tabular}{|c|c|c|c|c|c|c|c|c|c|}
\hline \multirow[b]{2}{*}{$\begin{array}{l}\text { Dimension } \\
\text { (range) }\end{array}$} & \multicolumn{3}{|c|}{ Cilazapril $(n=161)^{\star}$} & \multicolumn{3}{|c|}{ Captopril $(n=77)^{*}$} & \multicolumn{3}{|c|}{ Placebo/cilazapril $(n=72)^{\star}$} \\
\hline & Baseline & $\begin{array}{l}\text { Change } \\
12-0\end{array}$ & $\begin{array}{l}\text { Change } \\
24-12\end{array}$ & Baseline & $\begin{array}{l}\text { Change } \\
12-0\end{array}$ & $\begin{array}{l}\text { Change } \\
24-12\end{array}$ & Baseline & $\begin{array}{l}\text { Change } \\
12-0\end{array}$ & $\begin{array}{l}\text { Change } \\
24-12\end{array}$ \\
\hline $\begin{array}{l}\text { Tension-anxiety } \\
(0-32)\end{array}$ & 8.42 & $\begin{array}{l}-1.14 \\
(0.32)\end{array}$ & $\begin{array}{l}-0.18 \\
(0.27)\end{array}$ & 8.87 & $\begin{array}{l}-0.78 \\
(0.42)\end{array}$ & $\begin{array}{l}+0.01 \\
(0.42)\end{array}$ & 9.81 & $\begin{array}{l}-0.85 \\
(0.56)\end{array}$ & $\begin{array}{l}-1.12 \\
(0.53)\end{array}$ \\
\hline $\begin{array}{l}\text { Depression-dejection } \\
\quad(0-47)\end{array}$ & 6.26 & $\begin{array}{l}-1.22 \\
(0.40)\end{array}$ & $\begin{array}{l}-0.24 \\
(0.44)\end{array}$ & 7.54 & $\begin{array}{l}-2.22 \\
(0.81)\end{array}$ & $\begin{array}{l}+1.02 \\
(0.77)\end{array}$ & 7.85 & $\begin{array}{l}-0.45 \\
(0.94)\end{array}$ & $\begin{array}{l}-1.09 \\
(0.76)\end{array}$ \\
\hline $\begin{array}{l}\text { Anger-hostility } \\
(0-41)\end{array}$ & 4.86 & $\begin{array}{l}-0.43 \\
(0.33)\end{array}$ & $\begin{array}{l}-0.23 \\
(0.32)\end{array}$ & 5.06 & $\begin{array}{l}-0.34 \\
(0.50)\end{array}$ & $\begin{array}{l}-0.38 \\
(0.47)\end{array}$ & 6.28 & $\begin{array}{l}-0.17 \\
(0.76)\end{array}$ & $\begin{array}{l}-0.70 \\
(0.69)\end{array}$ \\
\hline $\begin{array}{l}\text { Vigour-activity } \\
\quad(0-32)\end{array}$ & 13.48 & $\begin{array}{l}+0.54 \\
(0.45)\end{array}$ & $\begin{array}{l}+0.41 \\
(0.38)\end{array}$ & 12.06 & $\begin{array}{l}+0.57 \\
(0.46)\end{array}$ & $\begin{array}{l}-0.32 \\
(0.50)\end{array}$ & 12.45 & $\begin{array}{l}+0.67 \\
(0.65)\end{array}$ & $\begin{array}{l}+0.98 \\
(0.51)\end{array}$ \\
\hline $\begin{array}{l}\text { Fatigue-inertia } \\
\quad(0-26)\end{array}$ & 6.99 & $\begin{array}{l}-1.13 \\
(0.39)\end{array}$ & $\begin{array}{l}-0.73 \\
(0.26)\end{array}$ & 7.87 & $\begin{array}{l}-1.90 \\
(0.57)\end{array}$ & $\begin{array}{l}+0.09 \\
(0.51)\end{array}$ & 7.66 & $\begin{array}{l}-1.09 \\
(0.65)\end{array}$ & $\begin{array}{l}-1.01 \\
(0.58)\end{array}$ \\
\hline $\begin{array}{l}\text { Confusion-bewilderment } \\
(0-22)\end{array}$ & 5.67 & $\begin{array}{l}-0.92 \\
(0.25)\end{array}$ & $\begin{array}{l}0 \\
(0.20)\end{array}$ & 6.19 & $\begin{array}{l}-0.83 \\
(0.36)\end{array}$ & $\begin{array}{l}+0.01 \\
(0.32)\end{array}$ & 6.19 & $\begin{array}{l}-0.43 \\
(0.46)\end{array}$ & $\begin{array}{l}-0.57 \\
(0.32)\end{array}$ \\
\hline $\begin{array}{l}\text { Total } \\
\quad(0-149)\end{array}$ & 51.13 & $\begin{array}{l}-5.46 \\
(1.41)\end{array}$ & $\begin{array}{l}-1.91 \\
(1.30)\end{array}$ & 55.57 & $\begin{array}{l}-7.34 \\
(2.44)\end{array}$ & $\begin{array}{l}+1.08 \\
(2.16)\end{array}$ & 57.70 & $\begin{array}{l}-3.56 \\
(3.01)\end{array}$ & $\begin{array}{l}-5.77 \\
(2.48)\end{array}$ \\
\hline
\end{tabular}

A high score indicates a poor QOL (except for vigour-activity).

$\star$ Number of patients providing information at both 0 and 12 weeks. 
Table 3 Percentage of patients unable to carry out usual activities, having no hobbies, with heart condition interfering with hobbies, with moderate or severe functional impairment, breathless with moderate or less tasks, and breathless with moderate or less effort

\begin{tabular}{|c|c|c|c|c|c|c|c|c|c|}
\hline & \multicolumn{3}{|c|}{ Cilazapril } & \multicolumn{3}{|l|}{ Captopril } & \multicolumn{3}{|c|}{ Placebo/cilazapril } \\
\hline & Baseline & $\begin{array}{l}\text { Change } \\
12-0\end{array}$ & $\begin{array}{l}\text { Change } \\
24-12\end{array}$ & Baseline & $\begin{array}{l}\text { Change } \\
12-0\end{array}$ & $\begin{array}{l}\text { Change } \\
24-12\end{array}$ & Baseline & $\begin{array}{l}\text { Change } \\
12-0\end{array}$ & $\begin{array}{l}\text { Change } \\
24-12\end{array}$ \\
\hline $\begin{array}{l}\text { Inability to carry out usual activities } \\
\text { (net improvement, } \% ;-=\text { improvement) }\end{array}$ & 31 & -9.2 & -1.6 & 44 & -12.7 & -10.3 & 34 & -9.7 & -4.8 \\
\hline $\begin{array}{l}\text { Days unable to carry out usual activities in last month } \\
(-=\text { improvement })\end{array}$ & 3.3 & $\begin{array}{l}-1.0 \\
(0.59)\end{array}$ & $\begin{array}{l}-0.4 \\
(0.35)\end{array}$ & 6.6 & $\begin{array}{l}-3.1 \\
(1.03)\end{array}$ & $\begin{array}{l}-0.5 \\
(0.86)\end{array}$ & 3.6 & $\begin{array}{l}-0.8 \\
(0.99)\end{array}$ & $\begin{array}{l}-1.1 \\
(0.44)\end{array}$ \\
\hline Have no hobbies (net increase $\% ;-=$ improvement) & 22.7 & +3.7 & -0.5 & 26.4 & +2.3 & -1.1 & 24.1 & +6.0 & -4.8 \\
\hline $\begin{array}{l}\text { Number of hobbies } \\
\quad \text { (those with hobbies; }+=\text { improvement) }\end{array}$ & 1.9 & $\begin{array}{l}-0.1 \\
(0.10)\end{array}$ & $\begin{array}{l}0 \\
(0.08)\end{array}$ & 2.0 & $\begin{array}{l}-0.1 \\
(0.18)\end{array}$ & $\begin{array}{l}+0.1 \\
(0.14)\end{array}$ & 2.0 & $\begin{array}{l}-0.1 \\
(0.11)\end{array}$ & $\begin{array}{l}+0.1 \\
(0.10)\end{array}$ \\
\hline $\begin{array}{l}\text { Heart condition interfered with hobbies }{ }^{\star} \\
\quad \text { (interfered } \% \text {; those with hobbies; }-=\text { improvement) }\end{array}$ & 22 & -12 & -2 & 31 & -14 & -3 & 20 & -10 & 0 \\
\hline $\begin{array}{l}\text { Mahler moderate or severe functional impairment } \% \\
\text { (net improvement, } \% ;-=\text { improvement) }\end{array}$ & 49 & +2 & NA & 59 & +7 & NA & 49 & -1 & NA \\
\hline $\begin{array}{l}\text { Mahler moderate or less tasks required to produce } \\
\text { breathlessness \% (net improvement, } \% ;-=\text { improvement) }\end{array}$ & 77 & -29 & NA & 87 & -20 & NA & 80 & -27 & NA \\
\hline $\begin{array}{l}\text { Mahler moderate or less effort required to produce } \\
\text { breathlessness \% (net improvement, } \% ;-=\text { improvement) }\end{array}$ & 68 & -1 & NA & 75 & +8 & NA & 69 & +4 & NA \\
\hline $\begin{array}{l}\text { Health status index } \\
\qquad(+=\text { improvement })\end{array}$ & 0.79 & $\begin{array}{l}+0.04 \\
(0.01)\end{array}$ & $\begin{array}{l}-0.02 \\
(0.01)\end{array}$ & 0.76 & $\begin{array}{l}+0.04 \\
(0.02)\end{array}$ & $\begin{array}{l}-0.01 \\
(0.02)\end{array}$ & 0.79 & $\begin{array}{l}+0.02 \\
(0.01)\end{array}$ & $\begin{array}{l}0 \\
(0.01)\end{array}$ \\
\hline
\end{tabular}

Net improvement is the percentage of patients getting worse minus the percentage getting better. Also given are: the number of days each month unable to perform usual activities and mean (SEM) change in days (12-0 weeks and 24-12 weeks); number of hobbies plus change (SEM) in number; and the health status index and change (SEM).

${ }^{\star}$ Quite a bit or extremely.

NA, not applicable to changes between 12 and 24 weeks.

placebo then cilazapril group. The effects of captopril or placebo are given for 0 to 12 weeks, and the effects of continuing cilazapril or captopril from 12 to 24 weeks.

After 12 weeks' treatment, significant drug improvements were found for most SIP dimensions in the active treatment groups, and in five dimensions (ambulation, social interaction, alertness, sleep and rest, and recreation) in the placebo group. There were no significant differences between the effects of placebo, captopril, or cilazapril at week 12 .

Table 2 shows the results for the six subscales of the POMS and the total score. After 12 weeks, patients in both actively treated groups showed a pronounced improvement in the subscales within the group. These changes were significant for both ACE inhibitors for depression-dejection, fatigue-inertia, and confusion-bewilderment. However, the improvements were not statistically different from those in the placebo group. The tendency for patients on active treatment to do better on the depression-dejection and anger-hostility scales is reflected in the total score where placebo produced an improvement of $3.56(p=0.20)$ compared with improvements of 5.46 and 7.34 in the cilazapril $(p<0.001)$ or captopril $(\mathrm{p}<0.01)$ groups.

Table 3 shows the baseline values and changes in regular activity, including hobbies, changes in the Mahler index of dyspnoeafatigue, and changes in the HSI. There was an improvement in ability to carry out regular activities, reduction in the heart conditions interfering with hobbies, and an improvement in the HSI on starting treatment. However, the three groups did not differ in these respects. Similarly, there was a trend towards reduction of the number of days that the patients could not pursue their regular activities. There was also an improvement in the severity of tasks needed to produce breathlessness. Again these changes were similar in the three groups. Paradoxically, the percentage of patients with no hobbies tended to increase and the number of hobbies pursued by those with hobbies tended to fall in all three groups on starting treatment. The Mahler functional impairment score and the effort required to produce breathlessness did not differ statistically between the groups.

Table 4 shows the mean difference between changes on active and placebo treatment, 95\% confidence intervals (CI), and effect sizes for

Table 4 Mean difference for cilazapril and captopril versus placebo (12-0 weeks) and cilazapril (24-12 weeks), compared with the group that continued with cilazapril

\begin{tabular}{|c|c|c|c|c|c|c|c|c|c|}
\hline \multirow[b]{3}{*}{ Dimension } & \multicolumn{3}{|c|}{ Cilazapril v placebo } & \multicolumn{3}{|c|}{ Captopril v placebo } & \multicolumn{3}{|c|}{ Cilazapril (starting v continuing) } \\
\hline & \multicolumn{3}{|l|}{$12-0$ weeks } & \multicolumn{3}{|l|}{$12-0$ weeks } & \multicolumn{3}{|l|}{ 24-12 weeks } \\
\hline & $\begin{array}{l}\text { Difference } \\
(S D)\end{array}$ & $95 \% C I$ & $\begin{array}{l}\text { Effect } \\
\text { size }\end{array}$ & $\begin{array}{l}\text { Difference } \\
(S D)\end{array}$ & $95 \% C I$ & $\begin{array}{l}\text { Effect } \\
\text { size }\end{array}$ & $\begin{array}{l}\text { Difference } \\
(S D)\end{array}$ & $95 \% C I$ & $\begin{array}{l}\text { Effect } \\
\text { size }\end{array}$ \\
\hline \multicolumn{10}{|l|}{$S I P$} \\
\hline Ambulation & $+1.33(9.1)$ & $-1.04,3.70$ & 0.15 & $+1.57(9.3)$ & $-1.23,4.37$ & 0.17 & $+0.05(6.8)$ & $-1.79,1.89$ & 0.01 \\
\hline Mobility & $+2.07(11.2)$ & $-0.86,5.00$ & 0.18 & $+1.67(10.8)$ & $-1.59,4.93$ & 0.15 & $+1.30(6.7)$ & $-0.53,3.13$ & 0.19 \\
\hline Body care and movement & $-0.01(6.0)$ & $-1.57,1.55$ & 0.00 & $+0.29(6.2)$ & $-1.58,2.16$ & 0.05 & $+1.12(4.5)$ & $-0.11,2.35$ & 0.25 \\
\hline Physical dimension & $+0.73(6.1)$ & $-0.86,2.32$ & 0.12 & $+0.87(6.1)$ & $-0.96,2.70$ & 0.14 & $+0.90(4.3)$ & $-0.26,2.06$ & 0.21 \\
\hline Psychosocial dimension & $-0.62(8.4)$ & $-2.81,1.57$ & -0.07 & $-0.10(9.1)$ & $-2.84,2.64$ & -0.01 & $+1.46(5.6)$ & $-0.05,2.97$ & 0.26 \\
\hline Total SIP & $-0.08(6.3)$ & $-1.71,1.55$ & -0.01 & $+0.56(6.5)$ & $-1.41,2.53$ & 0.09 & $+0.88(4.2)$ & $-0.25,2.01$ & 0.21 \\
\hline Total POMS & $+1.90(19.9)$ & $-3.81,7.61$ & 0.10 & $+3.78(22.8)$ & $-3.78,11.34$ & 0.17 & $+3.86(17.2)$ & $-1.21,8.93$ & 0.22 \\
\hline HSI & $+0.02(0.13)$ & $-0.01,0.05$ & 0.16 & $+0.02(0.14)$ & $-0.02,0.06$ & 0.15 & $+0.02(0.12)$ & $-0.01,0.05$ & 0.17 \\
\hline
\end{tabular}

A positive result is an improvement with active drug; $95 \% \mathrm{CI}$ for the difference and effect size.

SIP, sickness impact dimensions; POMS, total profile of mood states; HSI, health status index. 
the physical dimensions of SIP, the psychosocial dimension, and the total score. Also given is the mean difference between starting cilazapril at 12 weeks and continuing this drug from 12 to 24 weeks. In the physical dimension there was a very small effect size $(0.12-0.14)$ when cilazapril or captopril was given for 12 weeks. For the psychosocial dimension there was no improvement between 0 and 12 weeks for either cilazapril or captopril groups, and a small improvement for those starting cilazapril at 12 weeks. The total score also suggested only small differences in QOL as estimated from the SIP. The effect size on entering the trial and starting placebo (not shown in the table) was 0.23 for the physical dimension. The effects of cilazapril and captopril were not large and did not differ statistically from those of placebo. Nevertheless, the physical dimension showed small consistent effect sizes (between 0.12 and 0.21 ) in all groups. There was no consistent effect of the ACE inhibitors on the psychosocial dimension. For the total POMS there was a small positive effect compared with placebo for cilazapril (between 0.10 and 0.22) and captopril (0.17), a non-significant tendency to improve equivalent to that found with the SIP. Similarly, with the HSI a small positive effect size of $0.15-0.17$ was found for treatment with either cilazapril or captopril.

\section{Discussion}

While the effects of both ACE inhibitors on exercise tests were statistically better than placebo $^{7}$ the benefits in terms of QOL were modest. This is true for other QOL trials in $\mathrm{CHF}$ that have compared active treatment with placebo. ${ }^{19-21}$ Both cilazapril and captopril produced further improvement in ambulation and mobility compared with placebo, although the large number of outcome measures and comparisons suggest that these tendencies be interpreted with caution. Moreover, the general improvement on entering a trial may mask benefits, but having two baseline measuresone after randomisation and one just before starting the definitive treatment-may have reduced the trial effect.

The small effect sizes may result from the fact that we did not use sensitive enough measures of QOL. The SIP and POMS are not specifically for use in chronic heart failure and other methods may be preferred. However, the use of the Mahler scale did not to extend the information available from the NYHA class. The SIP has been sensitive to drug effects in many conditions including angina. ${ }^{22}$ However the low baseline scores for SIP dimensions suggest that either the patients were relatively free from disability (only $1 \%$ were NYHA class IV), or that the SIP is not a sensitive description of the particular problems of patients with CHF. Alternatively, patients may have to be followed for more than 24 weeks; however, the changes from 12-24 weeks with continuing treatment were very small.

The POMS was used by Blackwood and colleagues in a double blind trial in CHF comparing digoxin, xamoterol, and placebo. ${ }^{23}$ There were no differences in QOL among the three groups and this was attributed to the improvements that resulted from the special attention received by patients in the trial; attention that led to considerable improvements in the placebo group. The POMS was also used in a large trial of treating hypertension with cilazapril compared with nifedipine and atenolol. ${ }^{24}$ The subsection fatigue-inertia failed to improve on cilazapril and atenolol but did so on nifedipine $(p \leqslant 0.04)$. In our trial, tendencies to improve were observed for tension, depression, confusion, and fatigue with both ACE inhibitors. Improvements also tended to occur with placebo leading to no significant difference among the groups.

In a double blind trial, the Minnesota living with heart failure questionnaire ${ }^{25}$ was shown to be sensitive to the benefit of the inotropic agent pimobendan. ${ }^{19}$ In this trial a dose of $5 \mathrm{mg} /$ day significantly improved the Minnesota living with heart failure questionnaire scores and increased treadmill exercise duration compared with placebo. Improved questionnaire scores with $10 \mathrm{mg} /$ day were also accompanied by an improvement in exercise capacity. The Minnesota living with heart failure questionnaire was also used to assess QOL in SOLVD participants, ${ }^{3}$ and showed an improvement in the physical score with the long acting ACE inhibitor enalapril. ${ }^{20} \mathrm{~A}$ smaller trial also suggested an improvement in Minnesota scores with the inotrope enoximone but only 10 patients were followed in this three week crossover trial. ${ }^{21}$

The Mahler scale of dyspnoea-fatigue ${ }^{13}$ has been used to compare the effects on QOL of lisinopril versus captopril, ${ }^{6}$ and lisinopril versus placebo. ${ }^{26}$ In both trials the scale improved more with lisinopril. ${ }^{27}$ Lisinopril and cilazapril are longer acting ACE inhibitors than captopril but our study did not show any advantages in the use of long acting ACE inhibitors in CHF.

The probable psychological improvements with an ACE inhibitor may not reflect improvements in CHF. Patients with hypertension treated with captopril have an acceptable QOL compared with those treated with other antihypertensive agents, ${ }^{24} 2829$ and patients with both hypertension and depression improved when given captopril but not enalapril. ${ }^{30}$ Other studies have suggested that captopril may be preferable to enalapril in terms of QOL, ${ }^{31} 32$ although this has been disputed. ${ }^{33}{ }^{34}$ Certainly the central nervous system effect will depend on central nervous penetration of the different ACE inhibitors. ${ }^{35}$

A close relation is suggested between QOL measures in $\mathrm{CHF}$ and objective measurements of exercise tolerance. ${ }^{23}$ Exercise tolerance improved in our trial while the minute walk test (closely related to QOL measurements) ${ }^{23}$ did not achieve significance. The sample size was not calculated to detect a small difference. The Mahler dyspnoea scale and the assessment of hobbies produced inconsistent results and cannot be recommended. Of the other scales used in this trial we would recommend the use of the SIP, the POMS, and the few additional questions necessary for the HSI. Mild heart 
failure trials will have to be large enough to detect small effect sizes that are still important. We conclude that the improvements in QOL with the ACE inhibitors used in this study to treat mild to moderate heart failure were small.

This study was supported by a grant from F Hoffmann-La Roche, Basel, Switzerland.

1 The CONSENSUS Trial Study Group. Effects of enalapril on mortality in severe congestive heart failure; results of the cooperative north Scandinavian enalapril survival study (CONSENSUS). N Engl f Med 1987;316:1429-35.

2 Cohn JN, Johnson G, Ziesche S, et al. A comparison of enalof chronic congestive heart failure. $N$ Engl $\mathcal{F}$ Med 1991;325: of chronic 10 .

3 Yusuf S, for the SOLVD Investigators. Effect of enalapril on Yusuf S, for the SOLVD Investigators. Effect of enalapril on survival in patients with reduced ejection fractions and
congestive heart failure. N Engl f Med 1991;325:293-302.

4 The Acute Infarction Ramapril Efficacy (AIRE) Study The Acute Infarction Ramapril Efficacy (AIRE) Study Investigators. Effect of ramipril on mortality and morbidity of survivors of acute myocardial infarction with
dence of heart failure. Lancet 1993;342:821-8.

5 Pfeffer MA, Braunwald E, Moyé LA, et al, on behalf of the SAVE investigators. Effect of captopril on mortality and morbidity in patients with left ventricular dysfunction after myocardial infarction. Results of the survival and ventricular enlargement trial. N Engl f Med 1992;327:669-77.

6 Giles TD, Fisher MB, Rush JE. Lisinopril and captopril in the treatment of heart failure in older patients. Comparison inhibitor. Am f Med 1988;85(B):44-7.

7 Dössegger L, on behalf of the Cilazapril-Captopril Multicentre Group. Comparison of the effects of cilazapril and centre Group. Comparison of the effects of cilazapril and captopril versus placebo on exercise testing in chronic heart failure patients: a double-blind, random

8 Larsen J, Sykulski R, Jensen G, et al. Adaptive changes in the acute haemodynamic effects of cilazapril during chronic treatment. Comparison with long-term clinical effect. Eur $\mathscr{f}$ Clin Pharmacol 1996;50:433-41.

9 Sharpe DN, Douglas J, Coxon RJ, et al. Low-dose captopril in chronic heart failure: acute haemodynamic effects and long-term treatment. Lancet 1980;ii:1154-7.

10 The Criteria Committee of the New York Heart Association. Diseases of the heart and blood vessels; nomenclature and criteria for diagnosis. 6th ed. Boston: Little Brown, 1964.

11 Bergner M, Bobbitt RA, Carter WB, et al. The sickness impact profile: development and final revision of a health status measure. Med Care 1981;19:787-805.

12 McNair DM, Lorr M, Doppleman LF. Manual for the profile of mood states. San Diego: Educational and Industrial of mood states. San

13 Mahler DA, Weinberg DH, Wells CK, et al. The measurement of dyspnea. Contents, interobserver agreemeasurement of dyspnea. Contents, interobserver agreement, and physiologic corre

14 Bulpitt CJ, Fletcher AE. The measurement of quality of life in hypertensive patients: a practical approach. $\mathrm{Br} f \mathrm{Clin}$ Pharmacol 1990;30:353-64.

15 Bulpitt CJ, Fletcher AE. Measurement of the quality of life in congestive heart failure - influence of drug therapy. Cardiovasc Drug Ther 1988;2:419-24.
16 Wenger NK, Furberg CD. Cardiovascular disorders. In: Spilker B, ed. Quality of life assessments in clinical trials. New York: Raven Press, 1990:335-45.

17 Kazis LE, Anderson JJ, Meenan RF. Effect sizes for interpreting changes in health status. Med Care 1989; 27(suppl 3):S178-89.

18 Fletcher AE. Quality of life measurements in the evaluation of treatment: proposed guidelines. Br $\mathcal{F}$ Clin Pharmacol 1995;39:217-22.

19 Kubo SH, Gollub S, Bourge R, et al, for the Pimobendan Multicenter Research Group. Beneficial effects of pimobendan on exercise tolerance and quality of life in patients with heart failure: results of a multicenter trial. Circulation 1992;85:942-9.

20 Rector TS, Kubo SH, Cohn JN. Validity of the Minnesota living with heart failure questionnaire as a measure of therapeutic response: effects of enalapril and placebo. $A m \mathcal{F}$ Cardiol 1989;64:50-5.

21 Baligadoo SJ, Subratty H, Manraz M, et al. Effects of enoximone on quality of life. Int $\mathcal{f}$ Cardiol 1990;28 (suppl 1):S29-32.

22 Fletcher AE, McLoone P, Bulpitt CJ. Quality of life on angina therapy: a randomised controlled trial of transdermal glyceryl trinitrate against placebo. Lancet 1988;ii:4-8.

23 Blackwood R, Mayou RA, Garnham JC, et al. Exercise capacity and quality of life in the treatment of heart failure. Clin Pharmacol Ther 1990;48:325-32.

24 Fletcher AE, Bulpitt CJ, Chase DM, et al. Quality of life with three antihypertensive treatments-cilazapril, atenolol, nifedipine. Hypertension 1992;19:499-507.

25 Rector TS, Kubo SH, Cohn JN. Patients' self assessment of their congestive heart failure: II content, reliability and validity of a new measure - the Minnesota living with heart failure questionnaire. Heart Failure 1987;3:198-209.

26 Lewis GRJ. Lisinopril versus placebo in older congestive heart failure patients. Am f Med 1988;85:4(suppl 3B):48-54.

27 Feinstein AR, Fisher MB, Pigeon JG. Changes in dyspneafatigue ratings as indicators of quality of life in the treatment of congestive heart failure. $A m \mathcal{F}$ Cardiol 1989;64:50-5.

28 Croog SH, Levine S, Testa MA, et al. The effects of antihypertensive therapy on the quality of life. $N$ Engl $7 \mathrm{Med}$ 1986;314:1657-64.

29 Palmer AJ, Fletcher AE, Rudge PJ, et al. Quality of life in hypertensives treated with atenolol or captopril: a doubleblind crossover trial. 7 Hypertens 1992;10:1409-16.

30 Bosio A, Rosola R, Abbati C, et al. Antidepressant activity of angiotensin converting enzyme inhibitors. Current Therapeutic Research 1990;48:191-7.

31 Testa MA, Anderson RB, Nackley JF, et al. Quality of life and antihypertensive therapy in men. A comparison of captopril and enalapril. The Quality of Life Hypertension Study Group. N Engl f Med 1993;328:907-13.

32 The Treatment of Mild Hypertension Research Group. The treatment of mild hypertension study. Arch Intern Med 1991;151:1413-23.

33 Fletcher A. Captopril, enalapril and quality of life [letter]. $N$ Engl 7 Med 1993;329:505-6.

34 Steiner SS, Friedhoff AJ, Wilson BL, et al. Antihypertensive therapy and quality of life: a comparison of atenolol, captotherapy and quality of life: a comparison of atenolol, capto-
pril, enalapril and propranolol. F Hum Hypertens 1990;4: pril, ena.

35 O'Brien AJ, Bulpitt CJ. The effects of ACE inhibitors on cognitive function. Drugs Aging 1995;6:173-80. 